\title{
A Process Approach in the Teaching of Writing: Saving 21st Century Learners from Writer's Block
}

\author{
Hazlina Abdullah ${ }^{1, *}$, Azni Mohamed Zain ${ }^{1}$, Nursyuhada' Ab Wahab ${ }^{1}$, Mohd Muzhafar Idrus ${ }^{1}$, \\ Mas Rynna Wati Ahmad ${ }^{2}$ \\ ${ }^{1}$ Faculty of Major Language Studies, Universiti Sains Islam Malaysia, Bandar Baru Nilai, 71800 Nilai, Negeri Sembilan, Malaysia \\ ${ }^{2}$ Faculty of Social Science \& Humanities, Universiti Kebangsaan Malaysia, Bangi, Selangor, Malaysia
}

Received September 14, 2020; Revised October 25, 2020; Accepted November 25, 2020

\section{Cite This Paper in the following Citation Styles}

(a): [1] Hazlina Abdullah, Azni Mohamed Zain, Nursyuhada’ Ab Wahab, Mohd Muzhafar Idrus, Mas Rynna Wati Ahmad , "A Process Approach in the Teaching of Writing: Saving 21st Century Learners from Writer's Block," Universal Journal of Educational Research, Vol. 8, No. 12, pp. 7160 - 7174, 2020. DOI: 10.13189/ujer.2020.081283.

(b): Hazlina Abdullah, Azni Mohamed Zain, Nursyuhada’ Ab Wahab, Mohd Muzhafar Idrus, Mas Rynna Wati Ahmad (2020). A Process Approach in the Teaching of Writing: Saving 21st Century Learners from Writer's Block. Universal Journal of Educational Research, 8(12), 7160 - 7174. DOI: 10.13189/ujer.2020.081283.

Copyright $@ 2020$ by authors, all rights reserved. Authors agree that this article remains permanently open access under the terms of the Creative Commons Attribution License 4.0 International License

\begin{abstract}
Writing is described by many cognitive psychologists as one of the most complex intellectual activities undertaken by humans. Therefore, it is not surprising that students find it difficult to deal with writing tasks. They often feel anxious about how to write and reach the targeted words—a situation known as 'writer's block'. This paper describes how the process approach of writing can be used by teachers to assist students in completing a writing exercise. A case study of the implementation of process writing in English for Academic Purposes course at a tertiary institution in Malaysia is presented to illustrate the positive outcome of the process writing approach. The systematic research-based curriculum used in this course allows the authors to observe the process and progress made by the participants in this study. It includes an in-depth discussion on the non-linear and cyclical features of writing, and how the process writing approach can make writing a more flexible, adaptable and enjoyable operation as it allows ample time for intervention procedures, the writing of multiple drafts, audience feedback and delayed attention to editing - to lower students' writer's block. The ability of students to work through their writer's block in stages, enables the teachers to guide them into a step-by-step production of writing through this process.
\end{abstract}

Keywords Process Writing, Writer's Block, Non-Linear, Cyclical Features, EAP Classroom, 21st Century Learners

\section{Introduction}

Why is the skill of writing important and what are its purposes? Writing serves many purposes and it can be used in many ways, which is aptly summarised by Willig (1990) in Brown [1], "Writing is a key element in the search for meaning because it allows us to reflect on and to order our encounters with the world and the impact they make upon us. Equally importantly, we write to share thought and feelings with others through communications ranging from hastily written notes to formal, carefully argued essays on complex issues" (p.2).

Many cognitive psychologists have described writing as one of the most intricate and difficult cognitive activities undertaken by human beings. Thus, it is not surprising that students face problems whenever they are assigned essay writing exercises to complete. Most of the time when students are tasked to write an essay, they have to strive hard to reach the targeted number of words. Most of them will "chew their pencils, they shuffle their feet, they sigh, groan and stretch, they ask how much do we have to write?" [2] (p. 81), which is a situation known as 'writer's block'.

Informally referred to as 'white terror page', writer's block is defined as "a distinctly uncomfortable inability to write" [3] (p. 93). Although discussed more in the area of language, writer's block is also present in medical literature, 
which is commonly believed to be "a stress reaction that paralyses the ability to put thoughts into words" [3] (p. 93). Huston [3] further states that, "The right, or creative, side of the brain, seeks to create (in this case, write). This induces the left, or analytic, side of the brain to anticipate all the problems that this action could entail, causing it to go into "overdrive" and inhibit the ability to write" (p. 93). Acknowledging this problem, language teachers, especially writing teachers should be made aware that their students might be facing writer's block.

The writers' block could possibly be due to the negative attitudes of students towards English language learning which is linked to their poor performance in writing. Therefore, studies need to be conducted "to address their actual writing attitude, learning problems and writing interests in order to come up with the viable measures in the attempts to enhance the students' writing ability and interest" [4] (p. 1092). The perception is even worsened when students fear the language mechanics, such as the English grammar, which may impede their writing progress. According to a research by Saadiyah Darus and Kaladevi [5], who looked at 72 written essays by Form Four students in one semi-urban secondary school, students were weak in subject-verb agreement and the use of singular and plural forms. Such basic errors indicate that students have not mastered basic grammatical structures even though they have gone through many years of learning English [6]. The writers' block can be overcome if teachers try to address the problems at an early stage, and identify students' engagements and interest towards the writing activities and tasks being provided [7, 8].

It is commonly found that Malaysian higher education learners lack note-taking skills and this has caused problems when they need to listen to lectures and expand their ideas for writing essays [9]. With such challenge, there is a call for a new approach to tackle the problems so that their writing skills can be enhanced. Teachers need to embrace new teaching approaches which are radically different from those which were utilised in previous centuries. The approaches employed nowadays are required to be up-to-date, relevant, engaging and interesting in order to fulfill the needs of millennium learners [10].

Teachers no longer function as merely knowledge-transmitters but must play an active role as dynamic facilitators of learning [11], to cater to the demands of the multi-faceted platform of 21st century learners. The students of today are learning by 'doing' and the teacher acts as a coach, helping students as they work on their respective projects, hence, the role of teaching and learning has evolved tremendously, as compared to traditional modes employed previously. Students are also learning and making full use of the inquiry method, and this encourages them to collaborate with others-which is a microcosm of the real world they will experience, once they leave the classroom.
This paper, then, extends this dialogue. In the following pages, we will illustrate that process-based approach can function as an intervention to reducing writer's block. We will also demonstrate how these processes will serve as grounds through which learners engage with other learning-related concepts. These concepts such as critical thinking skills, communication skills, real-world problems, $21^{\text {st }}$ century learning, to name a few, are made visible through process-based approach.

\subsection{Process Approach to Writing}

There have been two approaches in the teaching of writing: the traditional product approach, which is mostly concerned with the ultimate product and "what the product should look like” [1] (p. 320), and the process approach which follows what writers actually do as they write. Chunling and Guoping [12] state that, "In essence, process approach to teaching writing focuses on the writing process rather than the final product” (p. 150). According to White and Arndt [13], a process-focused approach is an enabling approach with its goal to "nurture the skills with which writers work out their own solutions to the problems they set themselves" (p. 5). This means that they are responsible to develop all the 'unrefined' data into a synchronous message. They also have to perform toward a suitable and relevant style for presenting their message into writing.

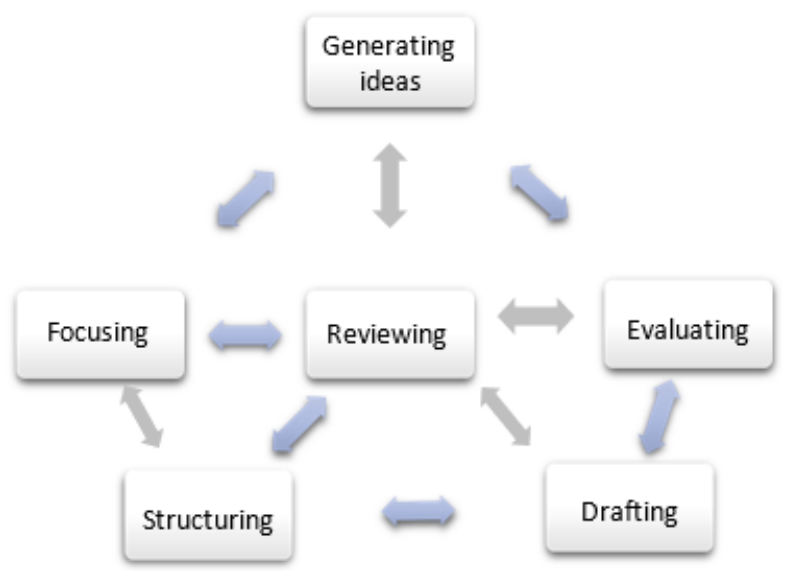

Figure 1. A model of writing [12]

Figure 1 encapsulates the complex and dynamic ventures implicated in writing. By looking at the processes involved, it is clear that there is much more to writing than just a way to test the application of linguistic codes. Nevertheless, the model, among many others, presents insights into pertinent ways of how writing is published at different levels that is context-dependent. That is, depending on the objectives of the class, this model, in one way or another, guides writers to establish their writing processes. It is vital that the teachers who teach students to write, take into account what students already know, find ways of setting learning to write in a 
context that makes sense to them, encourage students to enjoy writing, and expand their perceptions of writing. Teachers should also be aware of the possibility that an overemphasis on the flawless presentation of writing can discourage students to write anything at all.

\subsection{Executing the Process Approach in a Writing Class}

This paper demonstrates how teachers can use the process approach to help students in completing a writing exercise successfully, thus reducing the state of having writer's block. A case study of the implementation of process writing in an English for Academic Purposes (EAP) classroom is presented to illustrate the positive outcome of the process writing approach. The above model (Figure 1) will be used, which is coordinated into three phases:

Table 1. Three phases implemented in the EAP classroom

\begin{tabular}{|l|c|c|}
\hline Pre- Writing & $\begin{array}{c}\text { 1. Being motivated } \\
\text { 2. Getting ideas together } \\
\text { 3. Making plans/ outlines/ notes }\end{array}$ & $\begin{array}{c}\text { Generating ideas } \\
\text { Focusing } \\
\text { Structuring }\end{array}$ \\
\hline $\begin{array}{c}\text { Writing \& } \text { Making a first draft } \\
\text { Rewriting } \\
\text { (concentrating on WHAT to say) } \\
\text { 5. Revising/ re-planning/ } \\
\text { redrafting (concentrating on } \\
\text { HOW to say it) }\end{array}$ & Drafting \\
\hline Checking & $\begin{array}{c}\text { 6. Editing and proofreading } \\
\text { (accuracy of grammar/ } \\
\text { punctuation/ spelling) }\end{array}$ & Evaluating \\
\hline
\end{tabular}

As with reading, listening and speaking, students also need to be guided when writing. Normally, this will start with the first stage: pre-writing, where idea-generating is very much emphasised. This will involve the 'exploitation' of long-term memory which includes three kinds of memory store-episodic memory, semantic memory and unconscious memory [13]. Episodic memory refers to events, experiences and auditory images, while semantic memory includes information, ideas, attitudes and values. On the other hand, unconscious memory relates to emotions and feelings. As we are aware that writing serves different kinds of purposes, thus the idea generating process too varies according to its aims. For example, an imaginative type of writing will "tap episodic and unconscious memories" while discursive writing relies upon "semantic memory" as part of the process of creating its own genre [13] (p. 18).

In order to generate students' ideas, teachers can use brainstorming techniques either through demonstration by themselves or by the students. In the former, teachers make a list on the board and ask the class to suggest their ideas as well. For the latter, teachers can introduce a "snowball activity" [13]. This is done by listing any ideas to the assigned topic individually, then in pairs, followed by group work which finally proceeds with a whole class discussion. Thus, through this step-by-step process, more ideas are gained after each stage. Brainstorming can be used to select and develop a theme, to organise a suitable structure for an article or even to jot down ideas in order to work out a plot.

Apart from that, teachers can use questions to obtain and shape students' ideas because questions bring about interesting answers. Basic wh- questions can be used and as students' levels ascend, more complex ones can be introduced. For example,

- How does who affect what?

- Why does who affect what?

- Why is what affected by who? [13]

Teachers too can encourage students to make notes to prepare themselves with some basic ideas before they start writing. The notes can be unstructured without any specific organisation or structured with different sub-headings. Students can also write their notes in the form of a 'spidergram' which is quite similar to brainstorming.

As the saying goes 'seeing is believing', and visual aids are undoubtedly very useful to generate ideas. According to White and Arndt [13], visual materials can be categorised into three different groups:

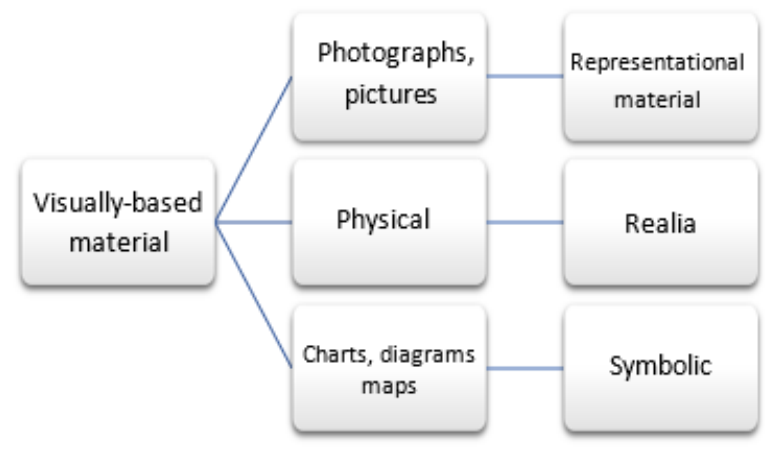

Figure 2. Categorisation of visual materials

Teachers can bring in the different types of visuals appropriate to the uses and aims of the writing tasks. For example, a picture of a flower, which is nebulous and liable to various interpretations, can be used as a stimulation to get students to write imaginary essays. Another way to generate ideas is through role-play and simulations. By having to act out the roles of different characters, usually in groups, students will gain broader insights on certain topics and thus, they can transfer this into their writing. Just as with visual aids, role-play and simulations can be adapted as stimuli for various types of writing.

Focusing and structuring are two other important elements in the pre-writing section. Every piece of written work must have particular ideas or messages to be conveyed to readers. Therefore, to impart the messages effectively, a focused and unified central idea must be present. In order to achieve this, teachers ought to provide students with the purpose of the writing exercise. The sense of purpose is essential because it steers students in 
making other decisions such as choosing the content or topic, and ways of expressing it. Teachers can also devise an exercise whereby students have to decide whether to take or reject ideas. Teachers will provide a long list of ideas, maybe from brainstorming activities held earlier, and students have to select the ideas that they believe are most useful for their essays.

Teachers should also help students in identifying their audience because "effective writers are critical readers of what they write" [13] (p. 69). Furthermore, the choice of appropriate content and style relies on a sense of audience. This will present a context to students, which will make the writing process much easier and more meaningful. Teachers can devise exercises for real audiences, for instance, writing complaint letters to newspapers, or assigning imaginary activities in the classroom. Here, the teacher facilitates thinking beyond the borders of the classroom as the role of teachers in the 21st century classroom should not mainly be that of a knowledge disseminator. Instead, teachers should work on helping students through the process of how to learn [10]. Hence, when simulation activities are carried out in class, targeted at a 'real' audience, students are encouraged to envision an actual situation which will require their processes of thinking and writing, outside of the classroom setting.

When ideas are gathered, the next fundamental process is to arrange and construct the essay. Structuring involves organising and grouping ideas, and determining which points come first or later in an essay. To help students in this aspect, teachers can construct some exercises which students have to think and consider their priorities; relate structures to main ideas; identify causes and effects; present arguments and counter-arguments and also ordering the available information. These kinds of exercises will train students to become better composers.

The next stage after pre-writing is the writing and re-writing stage. Here, another element of process writing-Drafting, is involved. In drafting, students are to write their first draft, which will be built towards the final product. Hence, using all the information in the pre-writing phase, students have to think of how to draw their readers' attention to continue reading, and finally leave with satisfaction. Writing a first draft however, "is often interrupted as the writer stops to read over the review, to get an idea of how the text is developing, to revise plans, and bring in new ideas or rearrange those already expressed” [14] (p. 23). There is a cyclical process here, but good writers usually focus on obtaining the right content first before checking on other details such as spelling, punctuation and grammar. Exercises that look at examples of good and bad openings, additions and endings; matching openings and endings; and completing a text are among a few examples that teachers can use in order to help students. In short, the drafting process emphasises what to say, and re-drafting focuses on how to convey it effectively.
The post-writing stage includes evaluation of the drafts. Teachers can correct their students' work by marking and highlighting mistakes on the paper [15]. In order to do this, teachers can use marking codes which is important to be sure that students are familiar with their mistakes. For example, 'WF' is used to indicate wrong form, 'WW' for wrong word, 'Sp' for spelling and many more. Apart from that, teachers can also conduct a whole class discussion where certain errors are dealt with at a certain time. This type of discussion will usually be held when teachers have detected a common pattern of mistakes made by most students in a class.

As so often, students always presume that their task is to write while the teachers' job is to assess. Yet, in the process approach, students are also part of the evaluation. Initially, teachers can develop certain criteria for evaluation where students will use them to check their own writing. Apart from that, conferencing and peer feedback can also be applied to assess and measure the quality of the written work produced. In writing consultation sessions, students and teachers can meet face-to-face and talk through the piece of writing. Any progress can be discussed, and support can be given in all aspects_-organisation, ideas, language and content. It also encourages students to "think about writing as something that can be organised and improved, and gives them the opportunity to talk about their writing and reflect on the process” [14] (p. 154).

Conversely, it provides teachers "a chance to listen, learn, and diagnose” [14] (p. 154) as for peer corrections, the editing can take place immediately after the writing, thus making it more meaningful to students. Furthermore, by correcting their friends' work, students can help to discern their own errors. Having explained points to friends, their own comprehension will be refined and defined. This is in line with the 21st century learning skills needed in promoting critical thinking among students, as they need to think critically in making judgements on their friends' work [16]. Thus, in doing so, students are applying the essential skills required during the writing process, where feedback plays an important role in completing the learning experience.

Reviewing is the final step to take in the writing process. After going through many processes from idea-generating, focusing, structuring, drafting to evaluating, students should then review their work to ensure 'perfect' results. Reviewing the text, "as if with a new pair of eyes” requires a sense of judgement where students "have a dual objective: to further develop critical capacities, and at the same time to enrich the repertoire of linguistic resources which are the essential tools for writing” [13] (p. 137).

As mentioned earlier, process approach does not see writing as a linear process. Instead, every stage can move 'back and forth' according to the needs of the students. For example, conferencing can be carried out during or 
after composition depending on the needs of the students. If the student has difficulties in structuring information, the student can seek advice from his or her teacher so that she or he would not have to struggle with the problem alone. Another advantage of the process approach is that it integrates all kinds of activities and skills under one lesson. It covers a range of activities from individual to whole class participation, and students are able to develop both their writing skills as well as oral skills.

Due to the dynamic process that this approach creates, 21st century learners are more likely to exercise their creativity via communication, critical thinking, problem-solving and life-long learning skills which are enhanced through this learning method. Hence, the flexibility of learning through process writing could be the solution in preventing writer's block among students, especially when they find it challenging to complete writing tasks.

\section{A Case Study of Process Writing in an EAP Classroom}

This section discusses a case study of how process writing assists students in completing an academic writing project in an EAP classroom. As mentioned earlier, the process, which can be a cyclical one, can lessen the situation of writer's block and also prepare students for 21st century learning.

\subsection{The EAP Course}

English for Academic Purposes (EAP) is a course offered at tertiary level, which emphasises reading and writing skills and the application of critical thinking into these two basic language abilities. EAP is a mandatory course at the place of this study - a public university located in Nilai, for students who have achieved Band 3 in their Malaysian University English Test (MUET). The course introduces students to research techniques, specifically reading and writing skills. As a higher level course (compared to proficiency courses), EAP is geared towards enabling students to propose research questions and topics, focus on specific aspects (such as causes, effects, and solutions in problem solving or current issues), and conduct a mini-research on a topic of their choice, based on specific thematic guidelines (outlined by the use of a textbook and set syllabus).

Among the course objectives for EAP at the research site include to familiarise students with effective academic reading and writing and to prepare students for academic and writing at tertiary level. By the end of the course, students are expected to achieve the outcomes of applying specific skills required for academic reading and writing, as well as to manage basic communication and teamworking skills with group members to complete given tasks and assessments [17]. As reflected in the objectives, it can be seen that this course is tailored for students who are 21st century learners as mentioned by Gerstein [10] where 21st century learning focuses on the exploration of authentic, real-world topics, issues, and problems in the contexts in which they occur.

The course materials for EAP are guided by a textbook, with three specific themes which provide the framework of topics and ideas, which students derive ideas from. Throughout the course, students are given three themes to work with, based on the textbook themes: risking change, globalisation, and technology [18]. The relevance of these topics and aspects fits well into the 21st century learning context, where critical thinking, problem-solving, communication, and life-long learning skills are all essential components which form the basis for expanding the learning experience among millennial students.

\subsection{Applying the Process Writing Approach in EAP Classes}

As the EAP course focuses on writing skills, with a primary emphasis on incorporating reading for content into their writing, students are prompted to link their ideas to the views of other writers through their readings, thus, enabling them to link creative and critical thoughts to writing. The process writing approach is adopted through the various stages of writing which are divided into brainstorming, drafting, writing, reviewing, and re-writing as a process to achieve the final product. This cyclical process also helps to reduce the situation of writer's block in students.

Throughout the 14-week duration of an entire semester, students are guided on how to develop research skills, and how to utilise reading and writing techniques to produce a research paper. Again, the guidance that students receive alleviates the condition of having writer's block, and it also prepares the students for life-long learning in order for them to thrive in the 21st century workforce.

The research paper is structurally arranged through the introduction, body paragraphs, integration of evidence, in-text citations, critical linking through responses and summations, conclusion, and references, whereby the final product is aimed at amounting to about 10 pages.

\subsection{Participants}

In a class of about 30 students, the EAP classroom is divided into groups. Each group consists of 3 or 4 group members, and as a team, students conduct the process writing approach in stages, as a large part of their overall assessment for the course depends on the writing of the paper. 1 intermediate group from the Faculty of Science and Technology was selected to be analysed in this study.

\subsection{The Writing Process}

The EAP course was carried out over a period of 14 
weeks during one semester and the writing process was divided into parts. During weeks 1-3, students engaged in idea-searching and sharing through brainstorming, open reading and group formation activities. Students were assigned into their respective groups, and they were asked to choose specific topics to brainstorm and propose as part of their Pre-Writing activity. By Week 4, topic approval and writing techniques were practised, using the textbook information as a basic guide for writing. Consultation sessions with the teacher, as well as group discussions, facilitated the idea-sharing process, hence, students were able to read, write, share, and apply critical thinking skills towards a specific topic, within the first few weeks of the course. By Week 5, students were already asked to start planning, structuring, and drafting their research papers, in order to move onto the actual writing stage of the process.

Table 2. The implementation of Process Writing

\begin{tabular}{|c|c|}
\hline WEEK & ACTIVITY \\
\hline $1-3$ & Brainstorming, Open Reading, Group Activities \\
\hline 4 & $\begin{array}{c}\text { Propose topics, narrow down scope of research based on } \\
\text { Research } \\
\text { Question and Focus }\end{array}$ \\
\hline $5 \& 6$ & $\begin{array}{l}\text { Begin Drafting: Students write out their first drafts } \\
\text { (Introduction, Body, } \\
\text { Integration of Evidence) }\end{array}$ \\
\hline 7 & Consultations with Teacher (before the Mid-Semester Break) \\
\hline $8 \& 9$ & $\begin{array}{c}\text { Peer Editing Activities (in-class): Students partake in group } \\
\text { discussions, checking each other's research papers based on } \\
\text { the "Peer Editing } \\
\text { Worksheet" }\end{array}$ \\
\hline $\begin{array}{c}10 \& \\
11\end{array}$ & $\begin{array}{c}\text { Consultations with teacher, revisions/amendments/changes } \\
\text { are made based on teacher and peer feedback }\end{array}$ \\
\hline 12 & Final checking of the revised version of their research papers \\
\hline $\begin{array}{c}13 \& \\
14\end{array}$ & $\begin{array}{c}\text { Submission of Final Drafts (the final week of the semester is } \\
\text { reserved for any other consultation sessions, if needed) }\end{array}$ \\
\hline
\end{tabular}

For the purpose of analysis, one of the groups in an EAP classroom was selected. The group consists of four members who are all first-year students from the Faculty of Science and Technology. The group of four initially proposed three topics, before one was finally selected as their research topic. From the brainstorming process, students were able to outline their ideas, based on interest and textbook readings on various issues related to the thematic content.

The topic "Cyberbullying" was chosen, under the theme of Technology, and it was narrowed down to focus specifically on "Solutions to Reduce Cyberbullying among the Younger Generation.” Interest-wise, these students stated that they felt a strong inclination towards writing something close to their field of study—science and technology, and because of the current issues surrounding the topic, cyberbullying was selected as the aspect they wanted to probe into, through further research. To illustrate the process, some excerpts from the students' first and final drafts of selected parts are included in the Appendices section at the end of the paper (Refer Appendices 1-6).

\subsection{Pre-writing}

In this stage of writing, students were asked to brainstorm and come up with possible ideas for their research paper topic. Based on Chapter 2 of the textbook [18], the students listed out research questions to prompt further research on topics of interest. The students decided to focus on the theme of "Technology," with a specific interest in the current issue of cyberbullying.

With further prompting through discussions and consultations with the teacher, the students focused on narrowing down of the topic based on specific areas of interest. They were asked to choose to focus on either the causes of the issue, the possible effects that it could lead to, or solutions to the problem. Through their brainstorming, idea-sharing, discussions, and consultations with the teacher, the group finally decided to narrow down the topic to solutions and how the issue could be resolved through suggested methods and efforts.

\subsection{Open Reading}

In Chapter 1 of the textbook [18], the students were exposed to the different ways of reading, to find resources and to generate ideas before the actual writing process occurs. Through open reading, the students engaged in opinion sharing and critical thinking. They were also guided on how to respond to their readings through skills such as paraphrasing, summarising, and synthesising.

The students decided on writing about cyberbullying, based on some open reading done on articles relating to causes of the problem. After discussing the content of the articles, this group decided to focus on the solutions that could be done to overcome the online bullying phenomena which included activities such as 'trolling' and the occurrence of keyboard warriors. When asked to come up with the research question, students listed down "Who are the parties responsible for resolving this issue?" and "What can be done to overcome cyberbullying issues among the younger generation?" Based on these possible research questions, students narrowed down their topic to focus on what parents, teachers, and peers could do to help reduce the problem of cyberbullying among the youth of today.

\subsection{Writing}

\section{Introduction}

As the students worked on their first draft, they took note of the structural content of their research papers. The textbook discusses the format of the introduction, but upon discussions with the instructor, the students came up 
with a more systematic structure i.e. beginning the draft with a few general statements, ending the first paragraph with a thesis statement, and then starting the second and third paragraphs with background information on the topic, as well as general citations.

After the general statements given at the beginning of the introductory paragraph, the students came up with the thesis statement: there are three ways to reduce cyberbullying among the youth which are through parental monitoring, teacher support and peer motivation. From this thesis statement, the topic sentences were developed, with specific reference to Chapter 4 [18], which provided a guide on how to write proper topic sentences, derived from the ideas listed in the thesis statement, as an overview.

The entire basis of the Introduction of the research paper focuses on general information on the topic, and the justification of why the topic is relevant as a research topic.

Students were asked to divide their essays into the following structure:

1. Introduction - One and a half pages

2. Body Paragraphs - One to two pages for each main point (six pages)

3. Conclusion - One and a half pages

4. Bibliography - five to ten references (one page)

\section{Body}

While writing the body paragraphs of their research paper, the students learned to integrate information as evidence, into their body paragraphs, and were asked to use proper in-text citations that match their reference list. Structuring the body paragraphs into topic sentence + explanation, Evidence \#1 + explanation, Evidence \#2 + explanation (and Evidence \#3 and \#4 if needed). They were then taught to link and make connections to conclude the point at the end of their body paragraphs for each main point.

Specific focus on Chapter 4 [18] was given during class sessions and consultations, as the aspect of integrating evidence and writing out in-text citations makes up a large part of the research paper. The students attempted to integrate evidence based on two methods: direct quoting, or paraphrasing [18], and this was linked to their topic sentences, which relate back to the thesis statement developed during the writing of the introduction paragraph.

Although the students seemed to have difficulty in writing topic sentences using varied vocabulary, they were able to clearly state the breakdown of their topics based on the thesis statement. Grammatically, the group did have some errors (see Appendix 4), but the sentence for the first topic was stated as: "The utmost solution to overcome this cyberbullying is by parental support.” The evidence integrated came from a few articles that dealt with parental roles and the importance of responsibility on the part of authoritative figures in families; which are the parents. Students were able to integrate further evidence on the other two points; focusing on teacher support and peer motivation as a way to prevent the increasing incidents of cyberbullying among youth.

\section{Conclusion}

In the conclusion section of the paper, the students used skills such as summarising and concluding in order to end their research paper on the right note. Using in-class practice and writing activities [18], students refined the writing of their conclusion by summing up the important ideas discussed, and leaving the reader (audience) with something to think about at the end of the paper. It could be seen in this part of the essay that analytical, critical and summation skills were put into practice.

At this stage of the research paper, it could be observed that the students attempted to use their summarising and concluding skills to end their discussion on solutions to the problem of cyberbullying. They managed to write two paragraphs in concluding their research by citing the important roles of the parents, teachers and peers in helping to reduce the cyberbullying phenomenon that exists today. They were also able to apply critical thinking skills based on Islamic knowledge (aqli and naqli elements), by citing a verse from the Quran about how people should not ridicule one another with mockery and name-calling. This was linked to the point that the group had written about; whereby cyberbullying was usually done via online modes, by people who liked to mock, find fault, trigger negative responses, and provoking actions through commenting activities on social media. Overall, the entire research paper was specifically focused on the aspect of finding solutions, which showed that the group's focus was consistent throughout their research process.

\section{Referencing}

As the students put together their research paper, they were guided with specific reference to Chapter 5 [18] on the various citations of resources that need to be included as part of their work. Students were introduced to the concept of in-text citations, collecting references, and writing them out in a bibliography or reference list format. They were also exposed to various styles of references based on the textbook, which identified the MLA and APA formats as common forms of citing academic work. Ultimately, students were asked to refer to the internationally recognised formats, but to use the USIM style of academic writing and citations, referring to the USIM's Handbook on Academic Writing [19].

\section{Rewriting}

Before the rewriting process, students were asked to carry out 'Peer Editing' or 'Peer Reviewing' activities, to check for structure and content in their drafts. This activity was carried out in groups, using a checklist to 
analyse whether the draft contains the essential parts of a research essay. The different groups were asked to comment on other groups' drafts and they conducted at least two rounds of peer reviewing, before the group could take back their draft and review the comments. The rewriting process occurred after the students had analysed their strengths and weaknesses (via peer commenting), and this was followed up with consultation sessions with the teacher. Students took note of the content, language, style, tone, grammar and vocabulary elements which were highlighted by the teacher through reading and a quick checking of their drafts (post peer reviewing).

Based on the peer comments given to this particular group, most of the research paper's structure followed the prescribed format. When asked how the paper could be improved, the peer editing worksheet stated that the group had included too much information that did not seem necessary as evidence to support their body paragraphs. The supporting details also seemed to need more elaboration, and explanation as they seemed a bit too short, and incomplete in its link to the topic sentences.

\section{Checking \& Revising}

Lastly, the revision process took place when students did a complete checking of their first drafts in their own groups, after making the necessary changes based on their peer review activities and consultation sessions with their teacher. At this stage, various language and vocabulary errors were looked into, and the students also amended the content through the integration of evidence and elaboration done in the body paragraphs. Some problems that arose after the checking of the first draft include:

1. dumped evidence

2. integrating unnecessary evidence

3. uncited information (improper quoting or

In order to avoid these problems, the students referred to Chapter 4 [18] which states examples of what type of evidence-writing to avoid; specifically dumped evidence and weak paraphrasing. During this final stage of writing, students were asked to do a thorough check on the errors and comments, based on both the peer reviewing section, and one-to-one consultations with the teacher.

Overall, it could be seen that through the process approach to writing, students had a more structured, systematic writing experience, as they were able to apply the skills of reading, writing, and critical thinking into their research. The incorporation and integration of evidence, though not always completely written in a balanced way, served to accentuate the ideas that were previously brainstormed in the pre-writing process. The Peer Review activity could be seen as a mode to facilitate checking and error-correcting [20], and this further enhanced the transition to the next stage of writing which was the checking and revising stage. In summation, the links between each stage in the entire process, resulted in a more systematic and structured end product, as students were able to bring in their ideas, yet at the same time review their writing through the assistance of their peers and teacher, throughout the processes that were followed in a step-by-step manner.

Earlier, it was mentioned that students would 'suffer' from writer's block, caused by the anxiety of being tasked to write. From the process of gathering ideas, structuring a focus, selecting suitable content to support ideas, drafting, peer reviewing, discussing, reviewing, and revising, students may find themselves 'stuck' at one point or another. However, the breakdown of stages in the process writing approach enables them to divide the daunting process of writing a research essay, into various parts, where the focus can be done in a more structured manner.

The fact that the course focuses on the process (rather than the finished product) allows the students to look at the writing task as a dynamic, ongoing process, and this prevents them from looking at the entire writing process as a tedious and methodological task. With the theoretical information from the textbook, guided by the teachers' instructions and guidance through consultations, combined with peer editing and feedback given by their fellow friends, students undoubtedly are able to break down their ideas, formulate problem and provide recommendation to problem, in a way illustrating critical thinking that has since taken place. They are also able to write out these ideas into a full writing product, which is scrutinised in stages, rather than as a final, finished product.

The ability of students to work through their writer's block in stages, enables the teachers to guide them into a step-by-step production of writing through this process, and this in turn will benefit both students and teachers, in aspiring to achieve the targeted goals related to the teaching and learning of writing. Thus, through process writing, it can be seen that the role of teachers in 21st century learning has evolved from the traditional ideal of teachers being merely disseminators of knowledge, to playing a more dynamic role as facilitator and 'coach' to their students.

\section{Conclusion}

There is no panacea for all problems of writing, but clearly process writing is one of the ways which can alleviate students' mental block when writing. Its non-linear and cyclical features make writing a more flexible, adaptable and enjoyable operation because it allows ample time for intervention procedures, the writing of multiple drafts, audience feedback and delayed attention to editing - all of which could possibly prevent, or at least lower students' writer's block. In encouraging students to prepare themselves for the 21st century 
workplace, the cyclical process of writing is quite apt as the components of communication, critical thinking, problem-solving and life-long learning are all incorporated into the entire writing procedure, within the EAP course. Although this paper has depicted that process writing will be of much help to students, there should also be a balance between process and product. As Brown [1] says, "Process is not the end; it is the means to the end" (p. 322). The eventual aim will still be the end product. Besides, the processes of pre-writing, drafting, structuring, evaluating and reviewing are all heading toward the final solid product. In a process writing method, it is acknowledged that no essay is perfect, however, the writer will have the chance to progress towards perfection by undergoing the cyclical process because “... good product depends on good process" [12] (p. 151). Hence, process writing aptly fits the needs of 21st century learning as it assists in alleviating the common problem of writer's block among students. This also works as a two-tier advantage to assist teachers in providing solutions to the teaching of writing skills, while simultaneously strengthening their role in encouraging and preparing 21st century learners for future endeavours.

\section{Appendices}

\section{Appendix 1: First Draft of Introduction}

\section{The Solutions to Reduce Cyberbullying among young generations}

The world's best future is said to lies on the young generations. But, nowadays they

become less qualified to be the next leader as they are extremely attached to the

technology more than ever. Technology, especially internet has becoming the most crucial

thing to complete their life as they use it daily to communicate with their friends, share

photos, gossiping with others and many more. However, because of this technology,

bullying can happen through cyberspace. Parents, teachers, and peers are the solutions to

overcome this issue from continuing give bad impacts towards society.

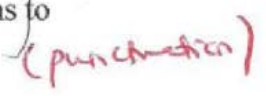

Most youth have been drawn into social media such as twitter, facebook, instagram

and more. This trend has led to increase reports of cyberbullying occurring in those social

media. Basically, cyberbullying referring to incidents where youth use technology to

harass, threaten or humiliate and making jokes of their peers without having the

intentions to bully them (Richard Donegan, Researcher in Elon University). For example,

cite

they can use smartphones or tablets to send hurtfull text messages or spread bad rumors

to others. They also recorded humiliating videos about someone and uploaded them for

the world to see and give comments that can hurt the victim emotionally. According to the

study from Cyber Wellness firm Kingmaker Consultancy, the statistic is about 43 percent

of the boys were had made fun by others online, and the amount is increased compared to

36 percent in 2013. About 4 percent increased from 2013 till the latest survey of girl that

had been reported being cyberbullied (The Straits Times, March 11, 2016). This shows

that the society must take action immediately as the issue is getting worse day by day. 


\section{Appendix 2: Final Draft of Introduction}

\section{The Solutions to Reduce Cyberbullying among young generation}

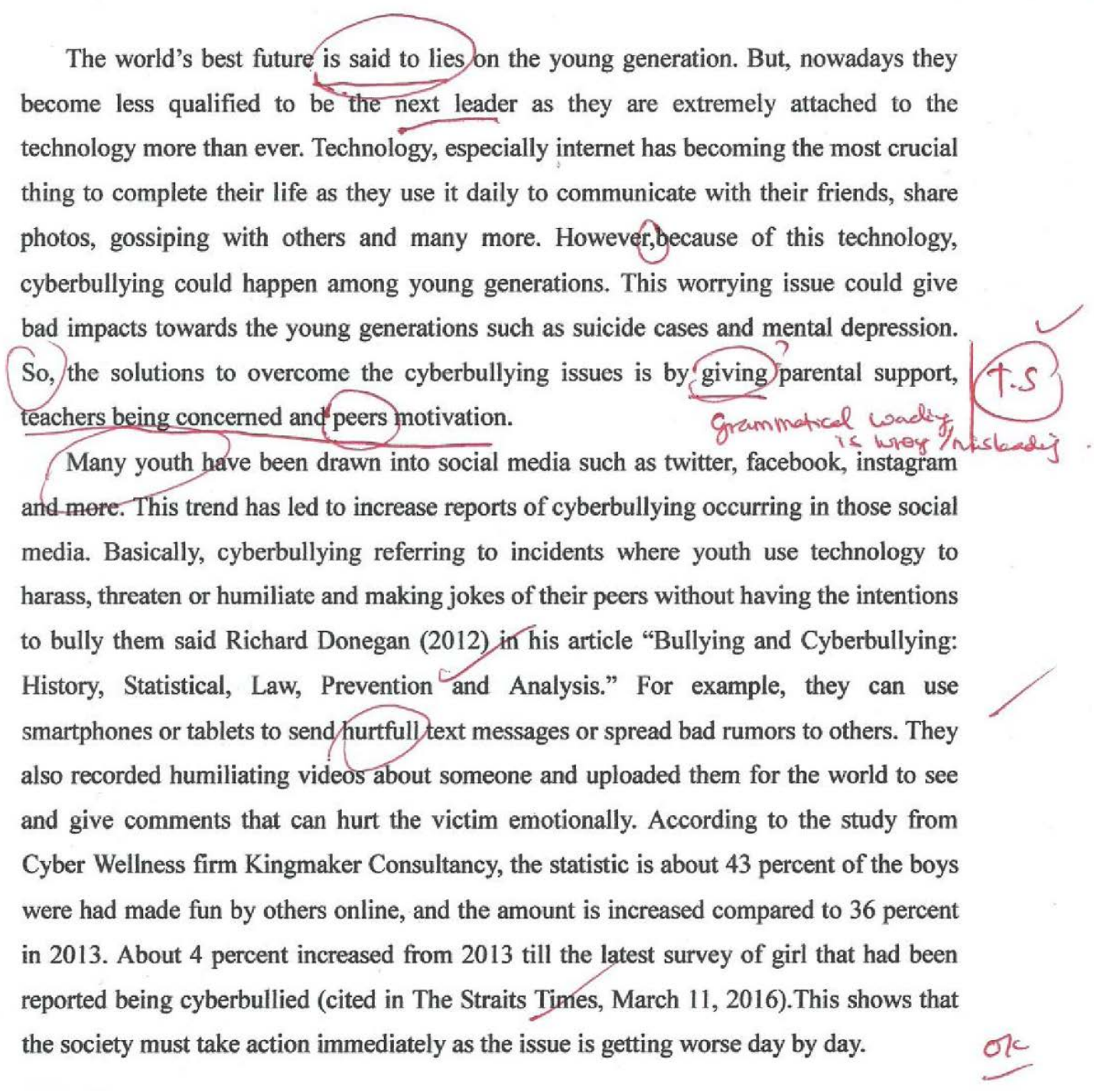




\section{Appendix 3: First Draft of Body Paragraph}

Parents need to be the ones their kids go to when something is wrong especially when they get involved in bullying. For this issue the solution that can be done is by parental support. Cyberbullying Research Center (CRC). (2010) writes an article about 'what parents can do to protect their children from cyberbullying' that one way the parents can do is to spend times to communicate with their children. Parents who have the greatest impact on keeping their children safe because they are the closest person to their children.

It is important for parents to develop an open dialogue with their children so they feel comfortable approaching them if confronted with an unpleasant online experience. An article about ' The parent's role in preventing cyberbullying' by Sameer Hinduja and Justin W. Patchin (2009) says that only a minority of teens who experience cyberbullying tell their parents. Much of this lack openness relates to the youth's perception that they will be blamed or will lose their computer, cell phone, or Internet privileges. Parents should conveying them that they will patiently listen to their problem or situation and respond in a nonjudgmental and responsible manner. Talk regularly and specifically with the children about online issues. Build trust with the children so that they will openly sharing their problem.

Privacy is also important, but safety is more important. Parent have a responsibility to know what their children are doing online. They should keep the child's computer in an open spot, such as the family room, where they can keep on eye their child's online activity. Do not allow it in the children's bedrooms. Resource E provides a

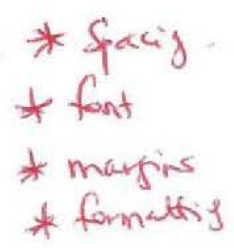




\section{Appendix 4: Final Draft of Body Paragraph}
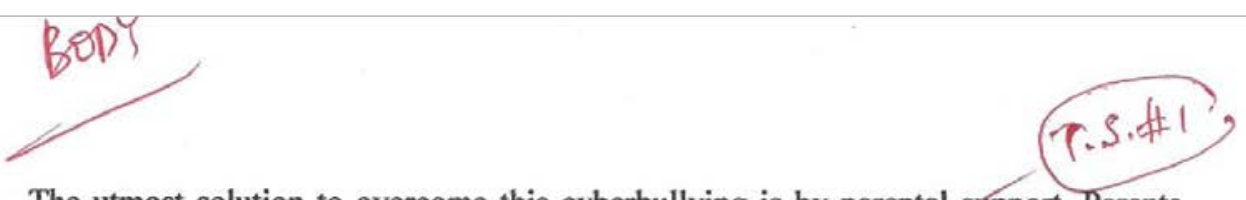

The utmost solution to overcome this cyberbullying is by parental support. Parents need to be the ones their kids go to when something is wrong especially when they get involved in bullying. For this issue the solution that can be done is by parental support. Cyberbullying Research Center (CRC). (2010) writes an article about 'what parents can do to protect their children from cyberbullying' that one way the parents can do is to spend times to communicate with their children. Parents who have the greatest impact on keeping their children safe because they are the closest person to their children.

It is important for parents to develop an open dialogue with their children so they feel comfortable approaching them if confronted with an unpleasant online experience. An article about ' The parent's role in preventing cyberbullying' by Sameer Hinduja and Justin W. Patchin (2009) says that only a minority of teens who experience cyberbullying tell their parents. Much of this lack openness relates to the youth's perception that they will be blamed or will lose their computer, cell phone, or Internet privileges. Parents should convey them that they will patiently listen to their problem or situation and respond in a nonjudgmental and responsible manner.They should talk regularly and specifically with the children about online issues and build trust with the children so that they will openly sharing their problem.

Privacy is also important, but safety is more important Parent have a responsibility to know what their children are doing online. They should keep the child's computer in an open spot, such as the family room, where they can keep on eye their child's online activity. Do not allow it in the children's bedrooms. According to Sameer Hinduja (2009) writes in his book " Bullying beyond the schoolyard: Preventing and responding to

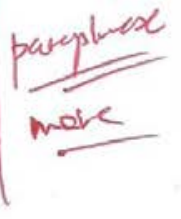
cyberbullying" that parents must monitor their children's online usage. In other words,

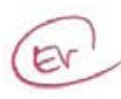
parents should establish rules about the access to the children's cell phones, text history, social networking sites, and other computer accounts that they may use for posting information. Decide if there will be limits on access to using technology to communicate with peers, such as no computer or texting after 9 p.m., during mealtimes, or until homework is done.

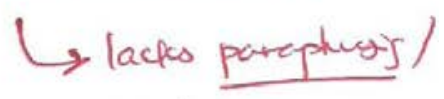




\section{Appendix 5: First Draft of Reference}

\section{Bibliography}

References :

1. Yuen Sin (March 11, 2016). The Straits Times, "If Youngster Harms Himself, His Computer May Hold Key."

2. Richard Donegan, Elon University (2012). "Bullying and Cyberbullying: History, Statistical, Law, Prevention and Analysis."

3. Prevention Resource Center (2012) . The Role of Teachers in Preventing Suicide. Available at $:$ http://www.sprc.org

4. Eva de Gosztonyi, Amanda Kelly and Jamie Orchard (2014,February). Global News : How can Schools Help Bullies Change Their Behaviour?

5. Anne OBrien (2011,October). Bullying Prevention : 5 Tips for Teachers, Principle, and Parents.

6. Lindsay Holmes (2014).Healthy Living.

7. Tom Mclntyre a Professor of Special Education (2003). The behavior Survival Guide For Kids.

8. Michael Nichols (1994). The Lost Art of Listening.

9. Robert Leahy (2010). The director of American Institute for Cognitive Theraphy

10. Corwin (2009). The parent's role in preventing cyberbullying. Corwin, www.corwin.com

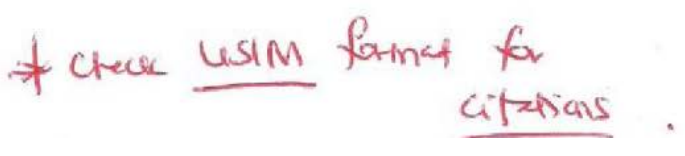


Appendix 6: Final Draft of Reference

\section{Bibliography}

References :

Al- Quran

Yuen Sin. 2016. If Youngster Harms Himself, His Computer May Hold Key. The Straits Times.11 March.

Donegan, R. 2012. Bullying and Cyberbullying:History, Statistical, Law, Prevention and Analysis. Elon University.

Prevention Resource Center. 2012. The Role of Teachers in Preventing Suicide. $<$ http://www.sprc.org >

Kelly,A and Orchard,J. 2014. Global News : How can Schools Help Bullies Change TheirBehaviour? <http://globalnews.ca/news.com>

OBrien,A. 2011. Bullying Prevention :5 Tips for Teachers, Principle, and Parents. $<\underline{\text { https://www.edutopia.org/blog/bullying-prevention> }}$

Holmes,L. 2014. Healthy Living.

Mclntyre,T. 2003. The behavior Survival Guide For Kids.

Nichols,M. 1994. The Lost Art of Listening.

Leahy, R. 2010. The director of American Institute for Cognitive Theraphy.

Corwin .2009. The parent's role in preventing cyberbullying. $<\underline{\text { http://www.corwin.com }>}$

Hinduja ,S. 2009. Bullying beyond the schoolyard : Preventing and responding to cyberbullying. P.203.

\section{Acknowledgements}

We are very grateful to experts for their appropriate and constructive suggestions to improve this article.

\section{REFERENCES}

[1] Brown, H. D. (1994). Teaching by Principles: Interactive language teaching methodology. NY: PrenticeHall Regents.

[2] Raimes, A. (1984). Anguish as a Second Language? Remedies for Composition Teachers. In Composing in a Second Language. London: Newbury House Publishers.

[3] Huston, P. (1998). Resolving Writer's Block. Canadian Family Physician. Vol. 44. pp. 92-97.

[4] Noriah Ismail, Supyan Husin \& Saadiyah Darus. (2012) ESL Students' Attitude Learning Problems, and Needs for Online Writing. GEMA Online Journal of Language Studies, 12(4), 1089-1107.

[5] Saadiyah Darus \& Kaladevi Subramaniam. (2009). Error Analysis of the Written English Essays of Secondary School

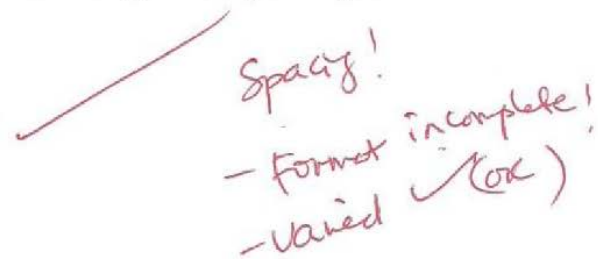

Students in Malaysia: A Case Study. European Journal of Social Sciences, 8 (3), pp. 483-495.

[6] Normazidah Che Musa, Koo Yew Liew \& Hazita Azman. (2012). Exploring English Language Learning and Teaching in Malaysia. GEMA Online Journal of Language Studies, 12 (1), pp. 35-51.

[7] Noriah Ismail, Suhaidi Elias, Intan Safinas Mohd Ariff Albakri, P. Dhayapari Perumal \& Indrani Muthusamy. (2010). Exploring ESL Students’ Apprehension Level and Attitude towards Academic Writing. The International Journal of Learning, 17(6), pp. 475-783.

[8] Hayati Akyol \& Nurhan Aktas (2018). The Relationship between Fourth-Grade Primary School Students' Story-writing Skills and Their Motivation to Write. Universal Journal of Educational Research, 6(12), 2772 2779 .

[9] Rosniah Mustaffa. (2006). The Effects of Culture on Students' Learning Styles. 3L The Southeast Asian Journal of English Language Studies, 12, pp. 83-94.

[10] Gerstein, J. (2017). What to Look For in 21st-Century Teaching. Retrieved from https://teach.noodle.com/what-tolook-for-in-21st-century-teaching-opinion

[11] Airil Haimi Mohd Adnan \& Hazlina Abdullah (2012). 
Communicative Language Teaching: Misconstructions and Misunderstandings in the Malaysian Context. English Language Journal Vol 5, pp. 79-93.

[12] Chunling Sun \& Guoping Feng (2009). Process Approach to Teaching Writing Applied in Different Teaching Models. English Language Teaching. Vol. 2 No. 1, pp. 150 - 155.

[13] White, R. \& Arndt, V. (1991). Process Writing. Essex: Longman.

[14] Hedge, T. (1988). Writing. Oxford: Oxford University Press.

[15] Hazlina Abdullah \& Harison Mohd. Sidek (2012). L2 Writing Feedback: Alignment of Instructional Planning and Implementation. English Language Teacher Education and Development (ELTED) Journal, Vol. 5 Winter 2012, pp. $15-24$.
[16] Stobaugh, R. (2013). Assessing Critical Thinking in Middle and High Schools. Eye on Education. Pp. 3-5.

[17] English for Academic Purposes Course Outline (2017). English Unit, Universiti Sains Islam Malaysia (USIM).

[18] Dollahite, N.E., Haun, J. (2012). Sourcework: Academic Writing from Sources. Second Edition. Boston: Heinle.

[19] USIM (2014). USIM's Handbook on Academic Writing. Bandar Baru Nilai: USIM Publisher.R. F. Voss, J. Clarke. Algorithmic Musical Composition, Silver Burdett Press, Londyn, 1986.

[20] Suliman Mohammed Nasser Alnasser (2018). Employment of the 'Peer Feedback' Technique in L2 Writing Classrooms: An Introductory Guide for Novice Instructors. Universal Journal of Educational Research, 6(8), pp. 1652 - 1658. 